\title{
Trophic state categorisation and assessment of water quality in Manjirenji Dam, Zimbabwe, a shallow reservoir with designated multi-purpose water uses
}

\author{
Beaven Utete ${ }^{1 *}$ and Joshua Tsamba ${ }^{2}$ \\ ${ }^{1}$ Chinhoyi University of Technology Department of Wildlife Ecology and Conservation P. Bag 7724, Chinhoyi, Zimbabwe \\ ${ }^{2}$ University of Zimbabwe, Biological Sciences Department, P.O Box MP 167, Mt Pleasant, Harare, Zimbabwe
}

\begin{abstract}
Intermittent, dire droughts and water abstraction pressures impact shallow man-made reservoirs with multiple designated water uses, often leading to water quality deterioration, and loss of biological integrity and utility value of a lake, threatening the livelihoods of lake shore communities. Thus, water quality information is crucial in setting up guidelines for freshwater resources management. In this study we investigated the water quality, determined the trophic state and assessed the influence of lake zones on the physical-chemical parameters of the Manjirenji Dam, Zimbabwe. Furthermore, we tested the applicability of two customary temperate water quality indices, the Canadian Council of Ministers of the Environment (CCME) Water Quality Index and the Carlson Trophic State Index, for a tropical lake system. Ten littoral and seven pelagic sites were sampled monthly over 9 months for the following water parameters: $\mathrm{pH}$, conductivity, turbidity, total dissolved solids, suspended solids, chlorophyll $a$, temperature, dissolved oxygen, water transparency, ammonia, nitrogen, nitrates, total and reactive phosphorus. Despite slight fluctuations/variations, water quality in the Manjirenji Dam was generally fair, with a CCME value averaging 78.1, and the Carlson Trophic State Index reflecting oligotrophy. Non-significant differences in water quality parameters between pelagic and littoral sites in the Manjirenji Dam reflect the high connectivity of different spatial zones in a shallow lentic system. Index scores of the adapted temperate water indices detect similar water quality conditions for the Manjirenji Dam, thus perhaps indicating their potential applicability. The current water quality data set for the Manjirenji Dam is vital for formulating prudent management strategies to formulate/ensure adequate multi-purpose water usage and service for this aquatic ecosystem.
\end{abstract}

Keywords: ecotone, lake zones, water quality, trophic state, Manjirenji Dam

\section{INTRODUCTION}

In large water bodies there are two distinct zones, littoral and pelagic, which respond differently to changes in lake levels (Wetzel, 2001). The littoral zone is defined as the zone of shallow water around the edges of lakes to the maximum depth at which light still penetrates to the bottom segments to allow macrophytic growth (Zohary and Ostrovsky, 2011). The pelagic zone is simply defined as the zone of open water (Zohary and Ostrovsky, 2011). The littoral zone tends to be more productive than the pelagic zone (Wetzel, 2001). In deeper lakes, which are defined as water bodies deep enough to stratify (Zohary and Ostrovsky, 2011), effects of excessive water level fluctuations may not be as noticeable as in shallow lakes, with visible changes only evident in the littoral zone (Nowlin et al., 2004). However, littoral zone changes can noticeably affect the pelagic zone (Zohary and Ostrovsky, 2011).

Most studies have focused mainly on the pelagic zone, as lakes have often been viewed as closed systems (Thorp and Covich, 2010). However, due to the interaction of the terrestrial and aquatic phases at the shoreline, studies comprising both the littoral and pelagic zone have been recommended (Zohary and Ostrovsky, 2011), given the potential cascading effects on the whole lake ecosystem. A study by Castilho-Noll et al. (2010) noted that zooplankton species richness in the pelagic zone was only $67 \%$ of that determined for the overall system. Some

*To whom all correspondence should be addressed

e-mail: mkaiyo@gmail.com

Received 6 April 2016; accepted in revised form 6 March 2017 planktonic species may appear in the littoral but not the pelagic zone (Kumar et al. 2004; Thorp and Covich, 2010). Thus a study encompassing both the littoral zone and pelagic zone would serve to give more representative information of the vertical and horizontal lake physicochemical structure which shapes biotic communities (Antenucci et al., 2003; Castilho-Noll et al., 2010).

The Manjirenji Dam, a relatively shallow reservoir located in the arid south-eastern part of Zimbabwe, is subject to wide waterlevel fluctuations, reaching a drastic $12.6 \%$ or $4.66 \mathrm{~m}$ from an average of $24.2 \mathrm{~m}$ in November 2012, then 18.9\% in September 2013 and increasing to just below 40\% in January 2014 (ZINWA, 2014). Though the main purpose of its construction was to supply irrigation water for the vast sugarcane-producing Mkwasine Estates, other multiple designated uses comprising domestic water abstraction, lakeshore irrigation, downstream wheat irrigation and small-scale hydroelectric power generation have evolved subsequently (Mazvimavi, 2010). In tandem with high deforestation rates, accelerated by transforming land initiatives, which deposit high silt loads into the dam, (Mazvimavi, 2010) there are wide water-level fluctuations, which is a threat to water quantity, quality and biotic integrity. However, the impact of aridity, water abstraction and human activities on water levels and water quality in Manjirenji Dam has scarcely received attention (Svubure et al., 2010), apart from concerns regarding water demand by sugarcane farmers (Mazvimavi, 2010). Since the Manjirenji Dam lacks permanent shoreline macrophytes and has an extended drawdown zone, knowledge of the impact of the withdrawing activities on the different lake zones is paramount (Thorp and Covich, 2010). 
There is a lack of crucial information on the trophic status and water quality of the reservoir. In order to address this knowledge gap, this study aimed to investigate the water quality and determine the trophic state of the Manjirenji Dam using two adapted customary temperate water quality indices, the Canadian Council of Ministers of the Environment (CCME) Water Quality Index (CCME, 2001) and the Carlson Trophic State Index (Carlson, 1977), for a tropical lake system. We also assessed the influence of lake zones on the water chemistry. The ultimate aim of this baseline water chemistry survey was to provide water quality data for the heavily utilised Manjirenji Dam in Zimbabwe; this data can be useful for future lake biotic integrity surveys.

\begin{tabular}{|l|l|}
\hline \multicolumn{2}{|c|}{ Morphometry of the Manjirenji Dam source (ZINWA, 2014) } \\
\hline Name & Manjirenji Dam \\
\hline Location & Chiredzi \\
\hline Construction began & $1964-1967$ \\
\hline Height & $51 \mathrm{~m}$ \\
\hline Length & $382 \mathrm{~m}$ \\
\hline Capacity & $284.2 \mathrm{million} \mathrm{m}^{3}$ \\
\hline Catchment area & $1536 \mathrm{~km}^{2}$ \\
\hline Surface Area & $2020 \mathrm{ha}^{2}$ \\
\hline Max water depth & $47 \mathrm{~m}$ \\
\hline Discharge capacity & $2730 \mathrm{~m}^{3} \cdot \mathrm{s}^{-1}$ \\
\hline Average depth & $1.35 \mathrm{~m}$ \\
\hline
\end{tabular}

\section{Study area - Manjirenji Dam}

Manjirenji Dam, located in the arid south-eastern part of Zimbabwe, is a rock-fill dam built on the Chiredzi River, and was constructed from 1964 to 1967 for conveyance of water to the irrigation scheme at Mkwasine Estates, near the town of Triangle to the south west (Fig. 1). The geology of the Manjirenji catchment area mainly comprises of sporadic deposits of ironbanded stones, and low-mineral igneous and calcite rocks (Svubure et al. 2010). The reservoir and its environment are protected and managed by Zimbabwe National Parks and Wildlife Authority (ZINWA, 2014). The lake's hydrological history and morphometry are summarised in Table 1.

\section{METHODS}

Ten littoral and seven pelagic sites were established so as to cover the entire Manjirenji Dam (Fig. 1). Monthly sampling was carried out from August 2013 to April 2014.

\section{Data collection}

Triplicate water samples for analysis were collected at each site with a $5 \mathrm{~L}$ Ruttner-type water sampler $\left(2.0 \mathrm{dm}^{3}\right.$ capacity), from the water surface to a depth of $3 \mathrm{~m}$ at $1 \mathrm{~m}$ intervals, and poured into one collective sample. The water sample was filtered and stored in pre-rinse acid-cleaned and sun-dried plastic bottles and immediately stored on ice before transportation to the laboratory for nutrient analysis. In-situ measurements of $\mathrm{pH}$, conductivity, turbidity, total dissolved solids, suspended solids, temperature and dissolved oxygen (DO) were done using a $\mathrm{pH}$, Neflorimeter, Conductivity and DO meter (HACH, LDO, Germany). Water transparency (Secchi depth, SD) was measured using a $20 \mathrm{~cm}$ diameter Secchi disc having alternating black and white quadrants. Chlorophyll $a$ was measured in situ at each site with a YSI 6600 VZ Multiparameter Water Quality Sonde. In the laboratory, the concentration of ammonia, total nitrogen,

\begin{tabular}{|c|c|c|c|c|c|c|c|c|}
\hline \multicolumn{7}{|c|}{ Water physical variables (mean \pm SD) for littoral zones in the Manjirenji Dam } \\
\hline Site & $\mathrm{pH}$ & $\begin{array}{c}\text { Temperature } \\
\left({ }^{\circ} \mathrm{C}\right)\end{array}$ & $\begin{array}{c}\text { DO } \\
\left(\mathrm{mg} \cdot \mathrm{L}^{-1}\right)\end{array}$ & $\begin{array}{c}\text { Conductivity } \\
\left(\mu \mathrm{S} \cdot \mathrm{cm}^{-1}\right)\end{array}$ & $\begin{array}{c}\text { TDS } \\
\left(\mathrm{mg} \cdot \mathrm{L}^{-1}\right)\end{array}$ & $\mathrm{SS}\left(\mathrm{mg}^{-} \mathrm{L}^{-1}\right)$ & Turbidity (NTU) & $\begin{array}{c}\text { Secchi } \\
\text { depth }(\mathrm{m})\end{array}$ \\
\hline L1 & $7.29 \pm 0.79$ & $26.53 \pm 10.92$ & $4.62 \pm 10.18$ & $79.30 \pm 28.05$ & $57.33 \pm 4.04$ & $84.00 \pm 26.06$ & $114.13 \pm 51.74$ & $1.99 \pm 0.37$ \\
\hline L2 & $7.44 \pm 0.55$ & $28.03 \pm 11.68$ & $4.47 \pm 10.87$ & $78.53 \pm 27.80$ & $54.67 \pm 3.51$ & $90.67 \pm 33.50$ & $119.7 \pm 49.89$ & $1.54 \pm 0.34$ \\
\hline L3 & $7.50 \pm 1.03$ & $30.17 \pm 12.65$ & $4.86 \pm 11.73$ & $80.87 \pm 28.44$ & $53.00 \pm 4.58$ & $77.67 \pm 43.92$ & $110.2 \pm 50.75$ & $1.99 \pm 0.48$ \\
\hline L4 & $7.74 \pm 0.73$ & $29.77 \pm 12.39$ & $4.77 \pm 11.51$ & $82.03 \pm 28.78$ & $54.67 \pm 2.89$ & $166.00 \pm 118.58$ & $221.07 \pm 160.63$ & $1.93 \pm 0.41$ \\
\hline L5 & $7.70 \pm 0.69$ & $30.47 \pm 12.80$ & $4.05 \pm 12.02$ & $80.30 \pm 28.46$ & $54.33 \pm 3.21$ & $84.33 \pm 52.00$ & $162.87 \pm 112.21$ & $1.66 \pm 0.37$ \\
\hline L6 & $7.54 \pm 1.06$ & $29.47 \pm 12.40$ & $4.78 \pm 11.48$ & $77.90 \pm 27.67$ & $54.33 \pm 3.51$ & $67.00 \pm 58.08$ & $102.27 \pm 72.46$ & $1.66 \pm 0.35$ \\
\hline L7 & $8.08 \pm 0.85$ & $28.37 \pm 11.65$ & $4.37 \pm 10.94$ & $77.47 \pm 27.70$ & $53.33 \pm 4.93$ & $84.00 \pm 48.59$ & $112.53 \pm 64.9$ & $1.71 \pm 0.42$ \\
\hline L8 & $7.76 \pm 0.63$ & $27.63 \pm 11.36$ & $4.44 \pm 10.62$ & $78.23 \pm 27.77$ & $51.00 \pm 7.55$ & $117.33 \pm 30.89$ & $123.00 \pm 29.46$ & $1.78 \pm 0.47$ \\
\hline L9 & $7.79 \pm 0.87$ & $28.10 \pm 11.58$ & $5.40 \pm 10.70$ & $79.13 \pm 27.62$ & $52.33 \pm 10.69$ & $140.33 \pm 74.14$ & $181.00 \pm 93.66$ & $1.78 \pm 0.47$ \\
\hline L10 & $7.44 \pm 1.00$ & $27.43 \pm 11.35$ & $5.43 \pm 10.47$ & $82.00 \pm 28.86$ & $57.67 \pm 10.07$ & $57.67 \pm 5.13$ & $72.67 \pm 14.57$ & $1.54 \pm 0.34$ \\
\hline
\end{tabular}




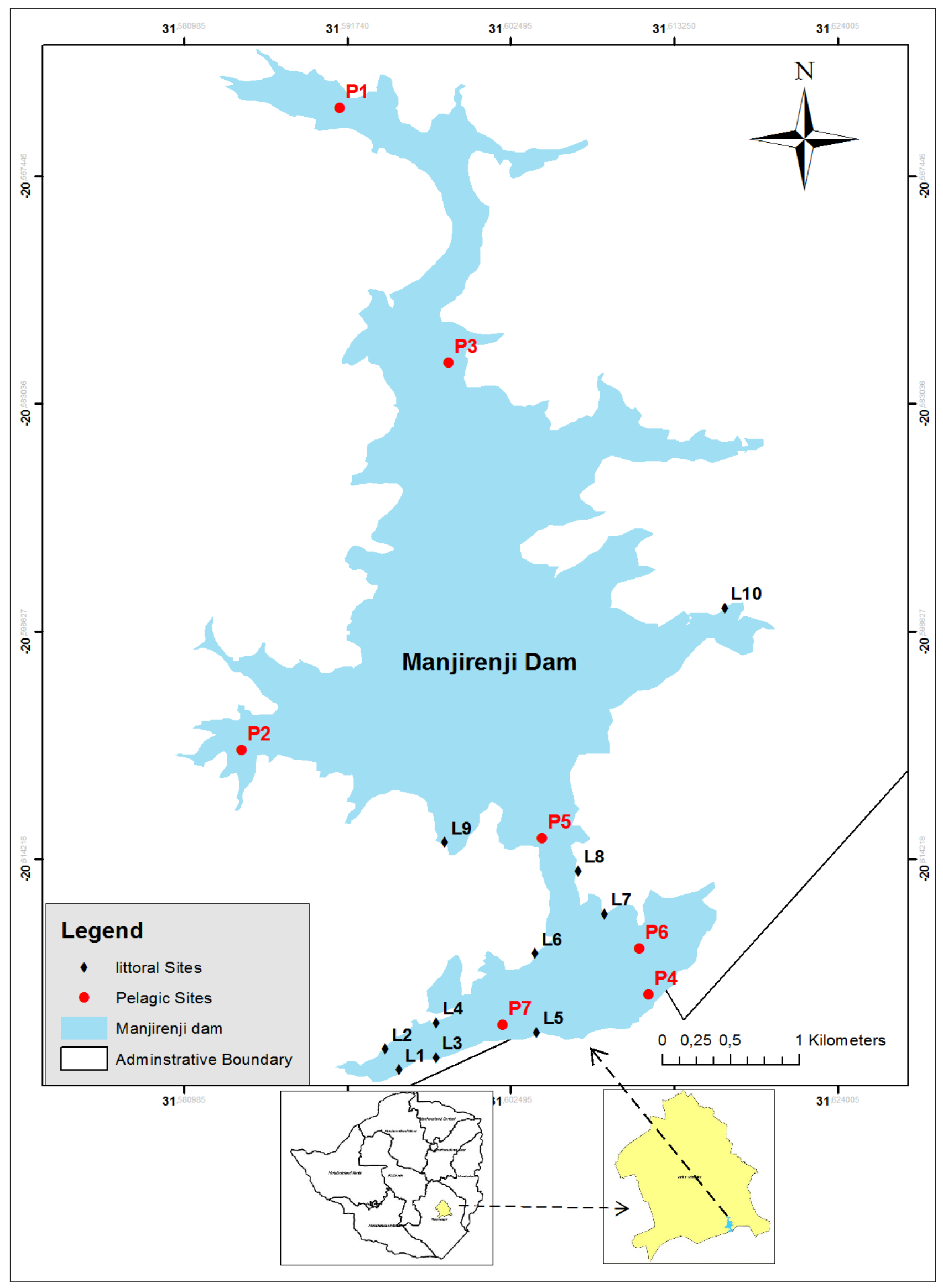

Figure 1

Location of sites in the Manjirenji Dam 
sulphates, and nitrates and total phosphorus were determined using standard colorimetric methods from EPA, Hach and Standard Methods (APHA, 1995).

\section{Data analysis}

The water quality parameters were separated on the basis of zonation and were grouped as littoral $(\mathrm{L})$ zone values and pelagic $(\mathrm{P})$ zone values. The physical-chemical data at all sites were subjected to repeated measurements to test for significant variation among sites sampled due to the distortion tendency associated with mean values. Thus, the spatial and temporal differences in physical-chemical parameters were investigated using one way ANOVA at 5\% level of significance using Past 2.16 software (Hammer et al., 2001).

Two measures were used for trophic categorisation of the reservoir - the Canadian Council of Ministers of the Environment (CCME) Water Quality Index (CCME, 2001) with the scoring criteria indicated in Appendix 1 (Table A1), and the Carlson Trophic State classification criteria by Carlson (1977). The CCME Water Quality Index uses set standard guidelines to compare against measured parameter values to produce a single value that represents the water quality of the entire water body. The index was calculated using a Microsoft Excelgenerated macro of CCME Water Quality Index Calculator 1.3. A Raup Crick cluster analysis to evaluate the similarities and dissimilarities of sites in both the pelagic and littoral zone was done.

\section{RESULTS}

For convenience, we separated the chemical aspects, consisting of $\mathrm{pH}$, conductivity, total dissolved solids, suspended solids, temperature, turbidity, dissolved oxygen and water transparency, from the trophic parameters, comprising of ammonia, chlorophyll $a$, total nitrogen, nitrates, sulphates and total phosphorus. The means (and standard deviations) of 14 physical and chemical variables measured in the littoral and pelagic zones of the Manjirenji Dam are shown in Tables 2-3 and 4-5 for littoral and pelagic sites, respectively.

\section{Physical-chemical parameters}

The $\mathrm{pH}$ values were slightly neutral with the highest value at Site $\mathrm{L} 7$, of $8.08 \pm 0.85$ (Table 2). A water temperature of $30.5^{\circ} \mathrm{C}$ was recorded at Site $\mathrm{L} 3$ and DO values averaging $4.2 \mathrm{mg} \cdot \mathrm{L}^{-1}$ were recorded across sites in both the pelagic and littoral zones (Table 2). Electrical conductivity values averaging $79 \mu \mathrm{S} \cdot \mathrm{cm}^{-1}$ across all sites (in both the pelagic and littoral zones) were recorded (Table 2 and 3). Turbidity was highest at Site L4 (averaging 221.07 NTU), and high suspended solid (SS) values of $166 \pm$ 118.58 and $140.33 \pm 74.14 \mathrm{mg} \cdot \mathrm{L}^{-1}$ were recorded at Sites L4

\begin{tabular}{|c|c|c|c|c|c|c|}
\hline \multicolumn{7}{|c|}{ Water nutrients (mean \pm SD) for littoral zones in the Manjirenji Dam } \\
\hline Site & $\begin{array}{c}\text { TP } \\
\left(\mathbf{m g} \cdot \mathbf{L}^{-1}\right)\end{array}$ & $\begin{array}{c}\text { TN } \\
\left(\mathbf{m g} \cdot \mathbf{L}^{-1}\right)\end{array}$ & $\begin{array}{c}\text { Nitrate } \\
\left(\mathbf{m g} \cdot \mathbf{L}^{-1}\right)\end{array}$ & $\begin{array}{c}\text { Ammonia } \\
\left(\mathbf{m g} \cdot \mathbf{L}^{-1}\right)\end{array}$ & $\begin{array}{c}\text { Sulphate } \\
\left(\mathbf{m g} \cdot \mathbf{L}^{-1}\right)\end{array}$ & Chlorophyll $a\left(\boldsymbol{\mu g} \cdot \mathbf{L}^{-1}\right)$ \\
\hline L1 & $0.12 \pm 0.06$ & $0.94 \pm 1.16$ & $0.03 \pm 0.02$ & $0.02 \pm 0.01$ & $73.24 \pm 34.69$ & $1.40 \pm 0.70$ \\
\hline L2 & $0.11 \pm 0.10$ & $1.54 \pm 1.32$ & $0.03 \pm 0.03$ & $0.02 \pm 0.01$ & $56.88 \pm 48.25$ & $1.87 \pm 0.11$ \\
\hline L3 & $0.12 \pm 0.13$ & $1.6 \pm 1.38$ & $0.01 \pm 0.01$ & $0.02 \pm 0.00$ & $60.36 \pm 15.63$ & $2.31 \pm 1.01$ \\
\hline L4 & $0.28 \pm 0.34$ & $1.53 \pm 1.32$ & $0.03 \pm 0.02$ & $0.02 \pm 0.00$ & $53.13 \pm 14.47$ & $1.23 \pm 0.34$ \\
\hline L5 & $0.04 \pm 0.03$ & $1.33 \pm 1.06$ & $0.01 \pm 0.00$ & $0.03 \pm 0.02$ & $50.52 \pm 38.35$ & $3.45 \pm 1.56$ \\
\hline L6 & $0.47 \pm 0.74$ & $0.8 \pm 1.22$ & $0.04 \pm 0.02$ & $0.02 \pm 0.00$ & $53.62 \pm 26.90$ & $0.97 \pm 0.11$ \\
\hline L7 & $0.12 \pm 0.14$ & $0.76 \pm 1.24$ & $0.04 \pm 0.04$ & $0.01 \pm 0.00$ & $65.23 \pm 25.95$ & $2.48 \pm 0.87$ \\
\hline L8 & $0.06 \pm 0.03$ & $0.77 \pm 0.99$ & $0.02 \pm 0.02$ & $0.02 \pm 0.01$ & $53.19 \pm 18.49$ & $2.21 \pm 0.33$ \\
\hline L9 & $0.28 \pm 0.39$ & $0.81 \pm 1.17$ & $0.03 \pm 0.03$ & $0.02 \pm 0.01$ & $67.66 \pm 23.09$ & $3.57 \pm 0.99$ \\
\hline L10 & $0.04 \pm 0.01$ & $0.57 \pm 0.94$ & $0.01 \pm 0.00$ & $0.02 \pm 0.01$ & $61.66 \pm 23.22$ & $3.01 \pm 0.77$ \\
\hline
\end{tabular}

\begin{tabular}{|c|c|c|c|c|c|c|c|c|}
\hline \multicolumn{7}{|c|}{ Water physical variable (mean \pm SD) for pelagic zones in the Manjirenji Dam } \\
\hline Site & $\mathbf{p H}$ & $\begin{array}{c}\text { Temperature } \\
\left({ }^{\circ} \mathbf{C}\right)\end{array}$ & $\begin{array}{c}\text { DO } \\
\left(\mathbf{m g} \cdot \mathbf{L}^{-1}\right)\end{array}$ & $\begin{array}{c}\text { Conductivity } \\
\left(\boldsymbol{\mu S} \cdot \mathbf{c m}^{-1}\right)\end{array}$ & $\begin{array}{c}\text { TDS } \\
\left(\mathbf{m g} \cdot \mathbf{L}^{-1}\right)\end{array}$ & $\begin{array}{c}\text { SS } \\
\left(\mathbf{m g} \cdot \mathbf{L}^{-1}\right)\end{array}$ & $\begin{array}{c}\text { Turbidity } \\
(\mathbf{N T U})\end{array}$ & $\begin{array}{c}\text { Secchi Depth } \\
(\mathbf{m})\end{array}$ \\
\hline P1 & $7.95 \pm 0.69$ & $28.17 \pm 11.56$ & $4.32 \pm 10.87$ & $81.70 \pm 28.68$ & $54.00 \pm 3.46$ & $70.67 \pm 42.15$ & $87.90 \pm 34.83$ & $2.11 \pm 1.02$ \\
\hline P2 & $7.83 \pm 0.84$ & $28.60 \pm 11.82$ & $4.40 \pm 11.07$ & $79.87 \pm 28.1$ & $57.33 \pm 15.70$ & $76.33 \pm 66.26$ & $117.37 \pm 73.02$ & $1.97 \pm 0.93$ \\
\hline P3 & $7.92 \pm 0.63$ & $26.00 \pm 10.46$ & $4.27 \pm 9.88$ & $81.03 \pm 28.43$ & $51.33 \pm 7.02$ & $81.67 \pm 70.87$ & $129.63 \pm 86.09$ & $2.03 \pm 1.11$ \\
\hline P4 & $7.43 \pm 1.04$ & $28.30 \pm 11.71$ & $5.08 \pm 10.81$ & $78.63 \pm 27.87$ & $54.67 \pm 3.79$ & $76.33 \pm 62.88$ & $107.23 \pm 65.19$ & $2.66 \pm 1.23$ \\
\hline P5 & $7.80 \pm 1.10$ & $27.90 \pm 11.38$ & $4.64 \pm 10.65$ & $80.13 \pm 28.29$ & $55.33 \pm 11.93$ & $84.33 \pm 66.23$ & $117.97 \pm 83.32$ & $1.89 \pm 1.02$ \\
\hline P6 & $7.82 \pm 0.94$ & $27.80 \pm 11.34$ & $4.18 \pm 10.71$ & $80.10 \pm 28.27$ & $57.00 \pm 7.00$ & $78.00 \pm 64.16$ & $113.83 \pm 74.83$ & $1.71 \pm 0.89$ \\
\hline P7 & $7.50 \pm 0.60$ & $27.603 \pm 11.45$ & $3.98 \pm 10.76$ & $80.73 \pm 28.61$ & $55.33 \pm 7.51$ & $77.00 \pm 59.86$ & $108.97 \pm 72.44$ & $1.78 \pm 0.98$ \\
\hline
\end{tabular}


TABLE 5

Water nutrients (mean \pm SD) for pelagic zones in the Manjirenji Dam

\begin{tabular}{|l|c|c|c|c|c|c|}
\hline Site & $\begin{array}{c}\text { TP } \\
\left(\mathbf{m g} \cdot \mathbf{L}^{-1}\right)\end{array}$ & $\begin{array}{c}\mathbf{T N} \\
\left(\mathbf{m g} \cdot \mathbf{L}^{-1}\right)\end{array}$ & $\begin{array}{c}\text { Nitrate } \\
\left(\mathbf{m g} \cdot \mathbf{L}^{-1}\right)\end{array}$ & $\begin{array}{c}\text { Ammonia } \\
\left(\mathbf{m g} \cdot \mathbf{L}^{-1}\right)\end{array}$ & $\begin{array}{c}\text { Sulphate } \\
\left(\mathbf{m g} \cdot \mathbf{L}^{-1}\right)\end{array}$ & $\begin{array}{c}\text { Chlorophyll } a \\
\left(\boldsymbol{\mu g} \cdot \mathbf{L}^{-1}\right)\end{array}$ \\
\hline P1 & $0.11 \pm 0.03$ & $0.70 \pm 1.06$ & $0.03 \pm 0.03$ & $0.02 \pm 0.01$ & $153.93 \pm 155.68$ & $2.10 \pm 0.30$ \\
\hline P2 & $0.06 \pm 0.01$ & $0.77 \pm 1.14$ & $0.04 \pm 0.04$ & $0.01 \pm 0.00$ & $48.89 \pm 37.38$ & $1.70 \pm 0.20$ \\
\hline P3 & $0.15 \pm 0.07$ & $0.76 \pm 1.02$ & $0.04 \pm 0.05$ & $0.01 \pm 0.00$ & $63.36 \pm 39.22$ & $3.32 \pm 1.01$ \\
\hline P4 & $0.12 \pm 0.04$ & $0.78 \pm 1.26$ & $0.05 \pm 0.07$ & $0.01 \pm 0.00$ & $55.20 \pm 19.74$ & $2.03 \pm 0.34$ \\
\hline P5 & $0.06 \pm 0.04$ & $1.63 \pm 1.12$ & $0.04 \pm 0.06$ & $0.02 \pm 0.01$ & $56.63 \pm 46.75$ & $1.27 \pm 0.56$ \\
\hline P6 & $0.31 \pm 0.25$ & $1.62 \pm 1.13$ & $0.05 \pm 0.03$ & $0.02 \pm 0.01$ & $59.91 \pm 44.32$ & $1.56 \pm 0.11$ \\
\hline P7 & $0.04 \pm 0.02$ & $1.61 \pm 1.21$ & $0.03 \pm 0.01$ & $0.02 \pm 0.01$ & $55.02 \pm 32.78$ & $1.21 \pm 0.87$ \\
\hline
\end{tabular}

\begin{tabular}{|c|c|c|c|l|}
\hline \multicolumn{5}{|c|}{ TABLE 6 } \\
\hline TN (mg·L-1) & Chlorophyll a (mg·L-1) & Phosphorus (mg·L-1) & Secchi depth (m) & Trophic class \\
\hline$<30-40$ & $0-2.6$ & $0-12$ & $>8-4$ & Oligotrophic \\
\hline $40-50$ & $2.6-20$ & $12-24$ & $4-2$ & Mesotrophic \\
\hline $50-70$ & $20-56$ & $24-96$ & $2-0.5$ & Eutrophic \\
\hline $70-100+$ & $56-155+$ & $96-384+$ & $0.5-<0.25$ & Hypereutrophic \\
\hline${ }^{*} 1.09$ & $2.10-2.26$ & ${ }^{*} 0.32$ & ${ }^{*} 1.82$ & ${ }^{*}$ Oligotrophic \\
\hline
\end{tabular}

and L9, respectively (Table 2). Relatively higher mean total phosphorus concentrations of $0.47 \pm 0.74$ and $0.31 \pm 0.25 \mathrm{mg} \cdot \mathrm{L}^{-1}$ were recorded at Sites L6 and P6, respectively (Tables 2 and 3). Comparatively consistent mean ammonia and nitrate values of $0.03 \mathrm{mg} \cdot \mathrm{L}^{-1}$ were recorded across sites in both the pelagic and littoral zones (Tables 3 and 5). Mean water transparency was highest in pelagic sites $\mathrm{P} 1, \mathrm{P} 3$ and $\mathrm{P} 4$ (with respective average Secchi depth values of 2.11, 2.03 and $2.66 \mathrm{~m}$ - see Table 4), whilst a high mean sulphate value of $153.93 \pm 155.68 \mathrm{mg} \cdot \mathrm{L}^{-1}$ was recorded at P1 (Table 5). High mean chlorophyll $a$ values of $3.45 \pm 1.56,3.57 \pm 0.99,3.32 \pm 1.01 \mu \mathrm{g} \cdot \mathrm{L}^{-1}$ were recorded at $\mathrm{L} 5$, L9 and P3.

There were no significant differences (Anova, $p>0.05$ ) in $\mathrm{pH}$ at different sites in the littoral zone. Though there were significant differences in $\mathrm{pH}$ in the pelagic zone; for example, Site P6 in the pelagic zone differed significantly from Sites P2 and P5. Whilst there were no significant differences in DO concentrations between the pelagic sites sampled, some sites in the littoral zones, such as L2, L4 and L9, differed significantly from L8 and L6. There were no significant variations in TDS values at all the littoral and pelagic sites. However, there were significant differences in the levels of suspended solids (SS) recorded between sites in both the littoral and pelagic zones. For instance, in the pelagic zone the levels of suspended solids at Site P6 differed from SS values at P2, P4 and P7. The mean Secchi depth was relatively consistent among littoral sites and did not differ significantly (Anova, $p>0.05$ ) between the littoral sites of the Manjirenji Dam. However, the mean Secchi depth differed significantly among pelagic sites in the Manjirenji Dam.

We recorded significant variations in total phosphate concentrations among sites in the littoral zone. There were no significant variations in nitrate concentrations among sampling sites in the pelagic zone, though we recorded some significant variations in nitrate concentrations among littoral sites.

Significant variations in TN concentration were recorded among sites in the pelagic zone, and between Site L6 and Sites L8 and L9 in the littoral zone of the Manjirenji Dam. Though we recorded no significant differences in EC values among sites in the pelagic zone the EC values at some littoral sites differed significantly. For instance, EC values at Site L8 differed significantly from L2 and L6, with EC values at Sites L1 and L4 differing significantly from those of Sites L9 and L10 respectively. We recorded no significant differences in ammonia concentrations among all sites in both the pelagic and littoral zones. There were significant variations in turbidity among littoral sites; for instance, turbidity values at Site L7 differed significantly from those recorded at L1 and L3. Chlorophyll $a$ concentrations did not differ significantly ( $p>0.05)$ among littoral shoreline sites.

The Carlson Trophic State Index and CCME Water Quality Index classification for lakes indicate that the Manjirenji Dam is oligotrophic (Table 6). Mean monthly (CCME) values reflect that the water in the Manjirenji Dam was in a fair quality for the initial 3 months of sampling (August-October), with CCME values ranging from $65-79$, punctuated by a period of good water quality (80-94) in the successive 4 months from November-February. It then reverted back to fair quality in March and April with an average CCME value of 78.6 (Table 7). Overall, the CCME index indicates that the water in the Manjirenji Dam is of fair quality with a mean CCME value of 78.1. Similarly, the Carlson Trophic State Index reflected a prevalence of an oligotrophic state in the Manjirenji Dam for the period we sampled. 
TABLE 7

The mean monthly canadian water quality index values for the Manjirenji Dam. * Monthly TSI classification states are added for comparison below. Oligotrophic $=$ OT

\begin{tabular}{|c|c|c|c|c|c|c|c|c|c|}
\hline Month & August & September & October & November & December & January & February & March & April \\
\hline WQI & 74.7 & 72.4 & 71.3 & 82.4 & 81.3 & 80.9 & 82.5 & 78. & 79.2 \\
\hline${ }^{\star}$ OT & OT & OT & OT & OT & OT & OT & OT & OT & OT \\
\hline
\end{tabular}

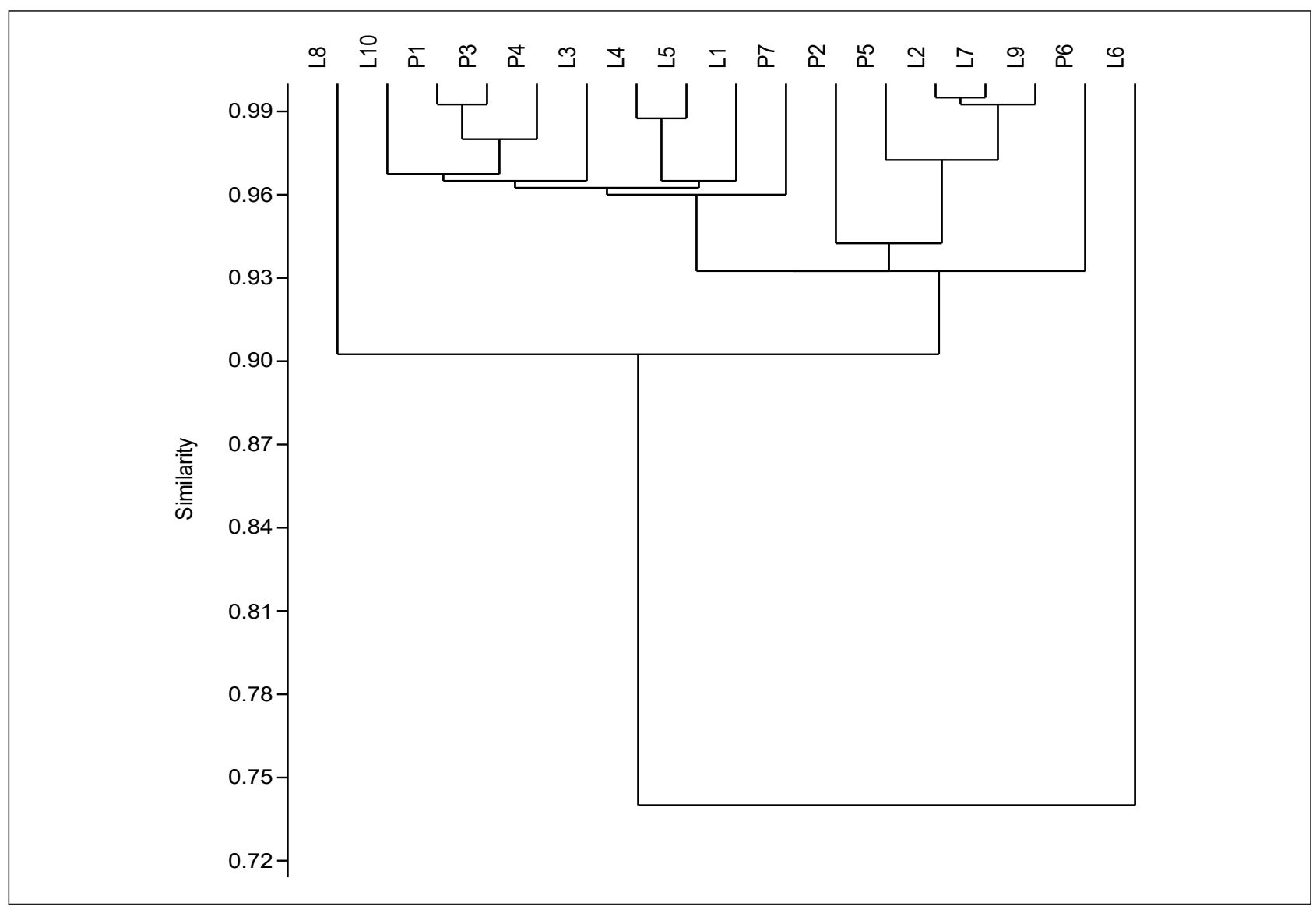

Figure 2

Raup-crick cluster analysis showing similarity of sites

\section{Site similarities}

The Raup Crick cluster analysis computation of site similarity (Fig. 2) shows no clear distinction of physical-chemical parameters between pelagic and littoral sites in the Manjirenji Dam, evidenced in the extensive inter-site dichotomy above the 0.95 similarity level, characterised by numerous branching-off of sites in Fig. 2. For instance, some littoral sites such as L2, L7 and L9 were similar to pelagic site P5. Sites L6 and L8 however, had distinct dissimilarities with other sites as shown in Fig. 2.

\section{DISCUSSION}

The two current temperate measures we used for trophic categorisation of the reservoir - the CCME Water Quality Index (CCME, 2001) with the scoring criteria indicated in Appendix 1, and the Carlson Trophic State classification criteria by Carlson (1977) - reflect that the water in the Manjirenji Dam is of fair quality and that the dam is in an oligotrophic state. Though various trophic state categorisation indices have been utilised for lakes and rivers in Southern Africa, the majority of indices are a modification of the Carlson Trophic State Index and use phosphorus as a determinant (Van Ginkel, 2002), whilst the choice for using the (CCME) Water Quality Index was premised on it being a convenient means of summarising complex water quality data that can be easily understood by the public, water distributors, planners, managers and policy makers (Lumb et al., 2006). Oberholster et al. (2013) used the phosphorus sensitivity index (LPSI) by isolating phosphorus as the key driver of productivity and an efficient indicator of early signs of eutrophication in the upper Olifants River and Lake Loskop. The phosphorus sensitivity index (LPSI) functions in a water system with hydraulic retention time between flood and recession events $\geq 100$ days with no drastic wide water-level fluctuations (WWF) and no extensive drawdown extents and zones (McDowell et al. 2004). Manjirenji Dam is prone to wide lake level fluctuations and has a pronounced drawdown zone devoid of both emergent and littoral shore macrophytes, inferring hydraulic residence/retention 
time of $<100$ days and thus limiting the use of the modified phosphorus sensitivity index (McDowell et al. 2004; Oberholster et al. 2013). The Carlson Trophic State Index encompass water transparency, chlorophyll $a$ and phosphorus concentrations and more accurately evaluates the trophic state of a lake which is phytoplankton dominated like the Manjirenji Dam (Carlson, 1977; Ejankowsk and Lenard, 2014). Modifications of the Carlson Trophic State Index arise due to its tendency to undervalue the trophic state of a macrophyte-dominated lake due to the significant amount of biogenic compounds accumulated in plant tissues (Ejankowsk and Lenard, 2014).

In order to validate the assessed water quality of the Manjirenji Dam we further tested another current temperate index, the CCME Water Quality Index, which indicated that water in the Manjirenji Dam is of fair quality with a mean CCME value of 78.1. This corroborates with the Carlson Trophic State Index which indicated an oligotrophic state of the dam. The CCME Water Quality Index integrates the measured physicochemical parameters of a lake into an algorithm relative to the local water quality standard guidelines and verifies conformity and deviations as water quality criteria as shown in Appendix 1 (CCME, 2001). For the Manjirenji Dam, the CCME Water Quality Index indicates that, though there are slight disturbances in the water quality, particularly in the drier months of August, September and October, as well as the post-rainfall month of April, overall, the water in the Manjirenji Dam is of fair quality. Reduction in lake levels in the drier months tends to reduce the dilution factor and increase the concentration of nutrients such as ammonia, nitrates, sulphates, and phosphorus, leading to poor water quality (Wetzel, 2001). Positive resonance between the two indices in categorising and detecting similar water quality for the Manjirenji Dam indicates their potential applicability to shallow tropical lakes though there is a need for rigorous validation and calibration for local conditions as the results may be coincidental.

Though there are two distinct zones, littoral and pelagic, which respond differently to changes in lake levels in large lakes (Wetzel, 2001), subtropical shallow lakes such as the Manjirenji Dam may present an important and differentiated set of conditions that makes them ecologically distinct from other types of lakes. In this study the extensive inter-site dichotomy above the 0.95 similarity level for all the physicochemical parameters between pelagic and littoral sites reflects the high connectivity facilitating longitudinal, vertical and lateral exchanges of water and materials between different spatial zones in a shallow lentic system (Scheffer and Van Nes, 2007). However, some distinct dissimilarities among littoral sites for nutrients such as nitrates, phosphorus and sulphate reflect intrinsic site-specific hydrochemical, hydraulic and morphometric variations (Dierberg, 1992). From a management perspective, this phenomenon presents a dilemma as the effects of nutrient control measures are not so clear-cut in shallow water bodies where interactions in the littoral zone are particularly important (Hildebrand, 2004).

For the entire sampling period, Manjirenji Dam was highly turbid, with the water characterised by reddish/dark-brownish patches. High turbidity of the Manjirenji Dam corroborates with high concentrations of suspended sediments (Wetzel, 2001). Mineral turbidity prevails in the dam linked to internal sediment resuspension and the external loading of the influent Chiredzi River, although we do not discount the contribution of the underlying geology of the Manjirenji catchment area, which mainly comprises of sporadic deposits of iron-banded stones, low-mineral igneous and calcite rocks, towards the reddish-brown colour of the water (Svubure et al., 2010). The incessant water waves and Langmuir circulations that we observed may also aid the horizontal redistribution of suspended minerals in shallow lakes such as Manjirenji (Hildebrand, 2004). Implications of physicochemical dissimilarities for biotic communities in shallow lakes derive from the almost uniform horizontal distribution of major drivers of productivity such as phosphorus, nitrates and sulphates, as these tend to determine dominant communities (Wang et al., 2011). An increase in the brackishness of the water as well as turbidity, as observed in the study, affects light penetration, which in turn poses a limitation on primary productivity (Fee et al. 1996); thus chlorophyll $a$ levels were almost uniform and not significantly different around the lake. Studies by Zohary and Ostrovsky (2011) indicate that chlorophyll $a$ concentration is directly dependent on light intensity, penetration, turbidity, and nutrient concentration and distribution along the shoreline.

Manjirenji Dam has designated multi-purpose water uses but is a shallow system with an average depth of $1.5 \mathrm{~m}$ and therefore delicate and prone to desiccation. The current water quality data set for the Manjirenji Dam is vital for formulating prudent management strategies to ensure adequate multipurpose water usage and services for this aquatic ecosystem. Moreover, at a time when water supply, demand and its quality is fast becoming a global concern as well as a current national concern in Zimbabwe (Svubure et al., 2010), it is imperative that Manjirenji Dam is not only continuously monitored but that control measures against pollution be instituted. Broadly our results reflect that there is scope for utilising the adapted current temperate CCME Water Quality Index (CCME, 2001) and the Carlson Trophic State classification criteria by Carlson (1977), as they provide a convenient means of summarising complex water quality data that can be easily understood by the public, water distributors, planners, managers and policy makers. This may be useful for water system managers in developing countries in the Southern African region, facing intermittent droughts and water quality and quantity deterioration, though we recommend rigorous testing of the indices encompassing shoreline and pelagic zone functionality, impact of seasonal aridity, climate change and irrigation water abstraction thresholds in multiple water systems before adoption for large-scale water quality monitoring programmes.

\section{ACKNOWLEDGEMENTS}

We express gratitude to Tamuka Nhiwatiwa, Linda Mhlanga, Patrick Mutizamhepo, and Elizabeth Munyoro of the Biological Sciences Department at the University of Zimbabwe, as well as Victor Muposhi, Accurate Mbauya and Sandra Zenda of the Department of Wildlife Ecology and Conservation Chinhoyi, Maureen Bepete and all the National Parks Authority staff at Manjirenji for their assistance at all stages of the field and laboratory work.

\section{REFERENCES}

ANTENUCCI JP, ALEXANDER R, ROMERO JR and IMBERGER J (2003) Management strategies for a eutrophic water supply reservoir, San Roque, Argentina. Water Sci. Technol. 47 149-155.

APHA (1995) Standard Methods for the Examination of Water and Wastewater $\left(16^{\text {th }}\right.$ edn $)$. American Public Health Association, Washington DC. 1041-1196.

CARLSON RE (1977) A trophic state index for lakes. Limnol. Oceanogr. 22 361-369. https://doi.org/10.4319/lo.1977.22.2.0361

CASTILHO-NOLL MSM, CAMARA CF, CHICONE MF and SHIBATA EH (2010) Pelagic and littoral cladocerans (Crustacea, Anomopoda and Ctenopoda) from reservoirs of the Northwest of Sao Paulo State, 
Brazil. Biota Neotropica 10 (11) 21-30. https://doi.org/10.1590/ S1676-06032010000100001

CCME (Canadian Council of Ministers of the Environment) (2001) Canadian environmental quality guidelines for the protection of aquatic life, CCME water quality index: Technical report. Canadian Council of Ministers of the Environment, Winnipeg, Manitoba.

DIERBERG FE (1992) The littoral zone of Lake Okeechobee as a source of phosphorus after a drawdown. Environ. Manage. 13 729-742. https://doi.org/10.1007/BF01868312

FEE EJ, HECKY RE and KASIAN SEM (1996) Effects of lake size, water clarity, and climatic variability on mixing depths in Canadian Shield lakes. Limnol. Oceanogr. 41 912-920. https://doi.org/10.4319/ lo.1996.41.5.0912

EJANKOWSKI W and LENARD T (2014) Trophic state of a shallow lake with reduced inflow of surface water. Arch. Environ. Prot. 40 (3) 3-11. https://doi.org/10.2478/aep-2014-0025

GASITH A and GAFNY S (1990) Effects of water level fluctuation on the structure and function of the littoral zone. In: Tilzer MM and Serruya C (eds) Large Lakes, Ecological Structure and Function. Springer-Verlag, Berlin. 156-171. https://doi. org/10.1007/978-3-642-84077-7_8

HAMMER O, DAVID A, HARPER T and RYAN PD (2001) Paleontological Statistics Software. Package for Education and Data Analysis. Paleontological Museum, University of Oslo, Oslo.

HILLEBRAND H (2004) On the generality of the latitudinal diversity gradient. Am. Nat. 163 (2) 192-211. https://doi.org/10.1086/381004

KOLDING J and VAN ZWIETEN PAM (2012) Relative lake level fluctuations and their influence on productivity and resilience in tropical lakes and reservoirs. Fish. Res. 115-116 99-109. https://doi. org/10.1016/j.fishres.2011.11.008

KUMAR A, TRIPATHI S and GHOSHI P (2004) Status of freshwater in $21^{\text {st }}$ Century: A review. In: Kumar, A and Tripathi G (eds) Water Pollution: Assessment and Management. Daya Publishers, Delhi.

LOPEZ-ARCHILLA AI and MOREIRA D (2004) Phytoplankton diversity and cyanobacterial dominance in a hypereutrophic shallow lake with biologically produced alkaline pH. Extremophiles 8 109115. https://doi.org/10.1007/s00792-003-0369-9

LUMB A, HALLIWELL D and SHARMA T (2006) Application of CCME Water Quality Index to monitor water quality: a case study of the Mackenzie River Basin, Canada. Environ. Monit. Assess. 113 (1-3) 411-429. https://doi.org/10.1007/s10661-005-9092-6

MAZVIMAVI D (2010) Investigating changes over time of annual rainfall in Zimbabwe. Hydrol. Earth Syst. Sci. 14 1-9. https://doi org/10.5194/hess-14-2671-2010
MCDOWELL RW, BIGGS BJF, SHARPLEY AN and NGUYEN L (2004) Connecting phosphorus loss from agricultural landscapes to surface water quality. Chem. Ecol. 20 1-40. https://doi.org/10.1080/02757540 310001626092

NOWLIN WH, DAVIES JM, NORDIN RN and MAZUMDER A (2004) Effects of water level fluctuation and short-term climate variation on thermal and stratification regimes of a British Columbia reservoir and lake. Lake Reserves Manage. 20 (2) 91-109. https://doi. org/10.1080/07438140409354354

OBERHOLSTER P, DABROWSKI J and BOTHA AM (2013) Using modified multiple phosphorus sensitivity indices for mitigation and management of phosphorus loads on catchment level. Fundamental Appl. Limnol. 182 1-16. https://doi. org/10.1127/1863-9135/2013/0378

SVUBURE O, SOROPA G, MANDIREGA S, RUSERE F, NDEKETEYA A and MOYO D (2010) Water conflicts on the Manjirenji-Mkwasine irrigation water supply canal, Masvingo Province, Zimbabwe. J. Agric. Ext. Rural Dev. 2 (10) 219-227.

THORP JH and COVICH AP (eds) (2010) Ecology and Classification of North American Freshwater Invertebrates ( $3^{\text {rd }}$ edn). Academic Press, London.

VAN GINKEL C (2002) Trophic status assessment. Institute for Water Quality Studies Department of Water Affairs and Forestry, Pretoria, South Africa.

SCHEFFER M and VAN NES EH (2007) Shallow lakes theory revisited: various alternative regimes driven by climate, nutrients, depth and lake size. Hydrobiologia 584 447-455. https://doi.org/10.1007/ s10750-007-0616-7

WANG L, CAI Q, XU Y, KONG L, TAN L and ZHANG M (2011) Weekly dynamics of phytoplankton functional groups under high water level fluctuations in a subtropical reservoir bay. Aquat. Ecol. 45 (2) 197-212. https://doi.org/10.1007/s10452-010-9346-4

WANTZEN KM, ROTHHAUPT KO, MORTL M, CANTONATI M, LASZLO GT and FISCHER P (2008) Ecological effects of water-level fluctuations in lakes: an urgent issue. Hydrobiologia 613 1-4. https:// doi.org/10.1007/s10750-008-9466-1

WETZEL RG (2001) Limnology: Lake and River Ecosystems. Academic Press, London.

ZINWA (Zimbabwe National Water Authority) (2014) Dams of Zimbabwe. Compendium. Government Publishers, Harare. 12-28.

ZOHARY T and OSTROVSKY I (2011) Ecological impacts of excessive water level fluctuations in stratified freshwater lakes. Inland Waters 1 47-59. https://doi.org/10.5268/IW-1.1.406

\section{APPENDIX 1}

\begin{tabular}{|c|l|l|}
\hline \multicolumn{3}{|c|}{ Canadian Water Quality Guidelines for the Protection of Aquatic Life (CCME, 2001) } \\
\hline CCME WQI & Category & Description \\
\hline $95-100$ & Excellent & $\begin{array}{l}\text { Water quality is protected with a virtual absence of threat or impairment; conditions very close to } \\
\text { natural or pristine levels }\end{array}$ \\
\hline $80-94$ & Good & $\begin{array}{l}\text { Water quality is protected with only a minor degree of threat or impairment; conditions rarely } \\
\text { depart from natural or desirable levels }\end{array}$ \\
\hline $65-79$ & Fair & $\begin{array}{l}\text { Water quality is usually protected but occasionally threatened or impaired; conditions sometimes } \\
\text { depart from natural or desirable levels. }\end{array}$ \\
\hline $45-64$ & Marginal & $\begin{array}{l}\text { Water quality is frequently threatened or impaired; conditions often depart from natural or } \\
\text { desirable levels. }\end{array}$ \\
\hline $0-44$ & Poor & $\begin{array}{l}\text { Water quality is almost always threatened or impaired; conditions usually depart from natural or } \\
\text { desirable levels. }\end{array}$ \\
\hline
\end{tabular}

